\title{
A Cognitive Metaphorical Analysis of Selected Verses in the Holy Quran
}

\author{
Ahmad Abdel Tawwab Sharaf Eldin ${ }^{1}$ \\ ${ }^{1}$ Wake Forest University, Department of Romance Languages, Winston Salem, North Carolina, USA \\ Correspondence: Ahmad Abdel Tawwab Sharaf Eldin, Department of Romance Languages, Wake Forest \\ University, North Carolina, USA. E-mail: brave107@yahoo.com
}

$\begin{array}{ll}\text { Received: September 24, } 2014 & \text { Accepted: October 6, } 2014 \quad \text { Online Published: November 25, } 2014 \\ \text { doi:10.5539/ijel.v4n6p16 } & \text { URL: http://dx.doi.org/10.5539/ijel.v4n6p16 }\end{array}$

\begin{abstract}
Metaphor has been generally contemplated and analyzed inside the schema of verbal discourse, scholarly works and humanistic studies. It has been identified with metaphorical language and has been viewed as quite recently a sort of aesthetic work, or something that is separated and disengaged from common language (Murray \& Moon, 2006). In addition, conventional learning of metaphors presents language as an abnormal or different method for using language (Goatly, 1997). Likewise, as Goatly has put it, scholars need metaphor strictly limited to writing and talk. Moreover, metaphor is viewed as something that fits in with abstract structures which is more concerned with novel or intriguing usages of words.

Lakoff \& Johnson (1980) presented an alternate idea and perspective of metaphor which is known as reasonable metaphorical classification. The theory underlying this new approach is that the reasonable metaphors enter our understanding of our general surroundings and they shape our demeanor of it. Appropriately, as pointed out by Lakoff \& Johnson (1980), metaphor, which is available in ordinary discourse, in every language, and is to a certain degree, has gotten to be culturally specific. Besides they contend that metaphors affect our method for considering the world and are discovered widely in a significant number of our languages, contemplations and activities.
\end{abstract}

Keywords: metaphor, conceptual metaphors, persuasion, metaphors in the Holy Quran

\section{Introduction}

Metaphor has been defined in a variety of ways. According to Merriam Webster's Dictionary (1999), metaphor is "a figure of speech in which a word or phrase denoting one kind of object, or idea and is used in place of another to suggest likeness or analogy between them, like drowning in money. Charteris-Black (2004:21) shows metaphor as "a linguistic representation that results from the shift in the use of a word or phrase." In this respect, Ross (1952:1457) views metaphor as "giving the thing a name that belongs to something else." The etymological origin of the word metaphor is from the Greek meta which means with and phor which means carry.

\section{Research Problem}

The present study sets to explore the usage of metaphors in the Holy Quran within Charteris-Blak's framework. As per this approach, metaphors are dissected and in a progressive methodical order. Such metaphors are delegated into semantic allegories, or theoretical illustrations, lastly as key representations. Moreover, the structure of examination is a composite of semantic, mental, and logical segments. The reason for this structure is to give elucidations, clarifications and capacities of metaphor's use in diverse classifications. The study tackles this approach to figure out how far metaphorical entities in the Holy Quran could be categorized into this characterization. Besides, the study tries to give deep understandings for the use of metaphors in the Holy Quran

\section{Objectives of the Research}

Metaphors which are employed in the holy Quran are varied in types and are different in their functions. These metaphors are used in the Holy Quran as a persuasive tool for both believers and unbelievers. They are used to persuade disbelievers to have faith in God and, at the same time, to strengthen the faith of believers in God. The metaphors in Quran fulfil two opposing functions. Metaphors could function as messengers of goodness for the individuals who have confidence in God and have solid confidence in Him, His messages and His dispatchers. Then again, they function as a way for the individuals who question in Him and deny His messages and His messengers. The present study intends to accomplish the following targets: 
- To determine the conceptual level of metaphor in the Quran, and how metaphors serve to facilitate the understanding of one conceptual domain, typically an abstract.

- To understand the power and influence of metaphor in Quran.

- To explore the role of metaphors in creating imageries in the readers minds, and its role in delivering the meaning in an indirect way

\section{Research Method}

This research uses a qualitative descriptive method. It describes some aspects of using metaphor in the Holy Quran and describes the collected data as well as analysis.

\section{Research Instrument}

The instrument in this research is the writer himself, as the subject of the research by reading and selecting the metaphorical words from the Holy Quran and reading other references that support to analyze the proposed data.

\section{Discussion of Data}

\subsection{The Components of Metaphor}

In linguistic view of metaphor, there are three components those form a metaphor. These components are topic, vehicle and ground. The topic is the entity referred to, and the vehicle is the notion to which this entity being compared. The base in which this comparison is being made from is called the ground. Knowles and Moon (2005) also identify these three components, they stated that metaphor consists of the metaphor (a word, phrase, or longer stretch of language); its meaning (what it refers to metaphorically); and the similarity or connection between the two. These three components have been referred to as vehicle, topic and ground.

\subsection{Types of Metaphor}

There are different types of metaphors. Ullmann (1978:242) shows that the first type is "concrete to abstract metaphors." This is the case of metaphorical extension of the usage of images drawn from the abstract sense to the concrete entity. Under this type, metaphor conveys sense impression to describe abstract experiences, for instance, "bitter feelings", "warm reception." The second type of metaphor is "synaesthesia metaphor" where words are transferred from one sense to another, from touch to sound and from sound to sight, like, "cold voice" or "piercing sound." The third type is called "anthropomorphic metaphor" where parts of the human body are used to refer to inanimate objects.

The obvious example for this type is "the neck of the bottle," "the mouth of a river." Leech (1974:150) states that the fourth type of metaphor is the "animistic metaphor" which attributes characteristics of animates to the inanimates. This is the case of the metaphorical utterances "an angry sky." Metaphor is employed in Quran as a cognitive way of memorizing and refreshing readers' minds about goals of their existence. It is used in Quran for different purposes, one of them is to move from something that is animistic or humanizing to something that is not inanimistic "inhuman" which is "promised paradise." That kind of metaphor is used to create new meanings and ideas, and to find a possible way to provide expressible thought. Generally, that kind of metaphor is employed to facilitate memorizing, and to communicate thoughts through many verses. Leech (1969:158) identifies another type which describes the "humanizing" type that attributes characteristics of human beings. It is important to mention that every metaphor employs two domains. The source domain and target domain. According to Lakoff \& Johnson (1980:5), source domain represents the equivalent figurative meaning. To understand different levels of meaning, we have to understand that it is the mind which is naturally embodied.

Lakoff and Johnson's view is that, the mind gets from and makes uses of bodily experiences such as perception and movement. In addition, the concepts are embodied in the sense that they are entrenched in the brain's nervous system. Lakoff and Johnson (1999:20) explain that concepts are neural structures in our brains. These neural systems are responsible for mental activities and for the process of conceptualization and reasoning. Richards (1936:96) mentions two elements that interact with each other during the metaphorical process; "tenor" and "vehicle."

On the one hand, tenor is the original element that is compared to another object from a different domain. On the other hand, "vehicle" is the borrowed entity in terms of which tenor is presented. In the same track, Black (1962:28) elaborates that metaphor works via a kind of interaction between its two elements. Richards (1936) explains that these elements are "tenor" and "vehicle", while Black (1962:28) calls them "focus" and "frame." "Focus" is the word used non-literally "metaphorically" and "frame" is the surrounding literal meanings. 
However, Black (1962:39) re-defines these elements as principal and subsidiary and explains that metaphor works by applying to the principal subject certain characteristics associated with the subsidiary one. For example, "John is a computer," is a metaphorical utterance, composed of a principal subject "boy" and a subsidiary subject "computer". These two subjects interact with each other through applying to the principal subject certain common characteristics of the subsidiary one (i.e., that he is prone to intelligence, good skills, and various talents).

\subsection{The Conceptual Types of Metaphor}

Lakoff and Johnson (1980:5) show that there are various types of metaphor from the cognitive perspective. They are divided into three types: structural, orientational, and ontological. Lakoff \& Johnson (1980:5) explain that structural metaphors are cases "where one concept is metaphorically structured in terms of another." The concept that needs explanation is understood via the corresponding source domain. They argue that the example, ARGUMENT IS WAR, is a clear example of this type. They explain that an ordinary activity like argument is understood in terms of war.

They affirm that this metaphor can be found in a lot of ordinary utterances like, "your claims are indefensible, he attacked every weak point in my argument." In all these expressions, the concept of war structures the activity of argument. They contend that in the metaphor, "argument is war," the argument is only understood in terms of war, but it is not war. They explain that if one engages in an argument, one does not use any kind of weapons.

The second conceptual type of metaphor is the orientational metaphor which has a certain approach on a concept. Lakoff \& Johnson (1980:14) define this type of metaphor as it "gives a concept a spatial orientation."The source domain infuses the target domain with certain direction. In the utterance "HAPPY IS UP," they explain that the target domain of happiness is structured via the source domain of verticality. In other words, people draw the picture of happiness in their minds as a vertical axis. Lakoff and Johnson (1980:14) state that orientational metaphor emerges from bodily experience. They clarify that the physical basis is the cornerstone of such metaphors.

So, when we say "I AM FEELING UP," the fact that upright position is associated with healthy attitude. A lower position is a reflection of unhappiness and desperation. Hence, the metaphor "SAD IN DOWN" or "I FELL IN DEPRESSION" is a reflection of specific meaning. Upward orientation tends to go together with positive evaluation, while downward orientation goes with a negative one. But positive-negative evaluation is not limited to the spatial orientation up-down.

Thus, the words like whole, balance, goal, front are mostly regarded as positive, while their opposites like, not whole, imbalance, no goal, and back are regarded as negative. An obvious example for that the phrase, "HALF THE MAN," which denotes someone who is not positively viewed, as in the example, "HE IS HALF MAN IN HIS DISCUSSION." Obviously, the "whole" versus "not whole" opposition is at work here.

The third type is the ontological "abstract" metaphor, which is a matter of viewing an abstract concept in terms of a physical entity. Lakoff \& Johnson (1980:27) view this type as a way of describing "non-physical thing as an entity or substance." They explain that such abstract entities are ideas, feelings and events. They provide an example in the metaphor, "INFLATION IS UP" Here, inflation is regarded as an entity that makes one confront it and feel opposite against it.

\subsection{Persuasive Power of Metaphor in Quran}

Metaphors have a persuasive effect on the recipients, as they are able to persuade and influence attitudes. Metaphors are employed to persuade the audience of certain views on any issue. In this respect, Miller (1979:155) argues that political speeches, which include metaphors, are more convincing to the audience. Metaphors enforce the strength of the message on the specific situation, as well as on the audience. Another significant factor in the process of persuading the audience by metaphors is the metaphor users need to establish and confirm their credibility. Credibility is the criterion against which speakers' efficiency is judged as it shows whether or not speakers are able to deal with the situation in which they are involved. On the other hand, Swanson (1978:164) confirms that metaphor "propels us on a quest for the underlying truth." He explains that the use of metaphor in discourse urges us to search for the hidden truth. He affirms that the metaphor provokes the audience to search for both the explicit and implicit messages.

To sum up, metaphor in discourse has a strategic function as it convinces the audience about the speaker's messages. It also helps the speakers to create new meanings and ideas to find an appropriate way of expressing the inexpressible thought. It also has a cognitive function as it facilitates the memorizing process for the audience. In addition, it enables the speaker to communicate meanings and thoughts. In short, the role of metaphors deserves to be explained as it shows that language is not only a medium of statements. Rather, it is also a tool of 
communicating, expressing, and creating new ideas and meanings in the conceptual domain. To get more understanding of the conceptualization and the conceptual domain, one has to start examining the basic principles of cognitive linguistics.

\section{Analyzing Data}

In fact, there are many colorful images drawn in the Quran and have been known to the Arabs from the time of the Quran's revelation to the Prophet Mohammed (peace be upon him) up till the present day. For Muslims, Quran is the word of Allah and contains devotions and instructions which are full of both literal and figurative styles. There are certain occasions on which certain styles are used more than others for some reasons. These can be briefly mentioned into two points; the first is to show the Arabs at the early stages of Islam when Arabic poetry was presented with a strong challenge from the Quran on the linguistic level. The second is to attract Arabs and non-Arabs to embrace Islam. We can see from the following verse how the Quran uses metaphor to create figurative expressions and produce its own forms of discourse in which an argument is introduced. The researcher attempts in the following part to explain the concepts of metaphors employed in the following verses of the holy Quran. In each verse, there will be a detailed explanation.

(أنزل من السماء ماء فسالت أودية بقدرها فاحتمل السيل زبدا رابيا ومما يوقدون عليه في النار ابتغاء حلية أو متاع زبد مثله كذلك يضرب الله الحق

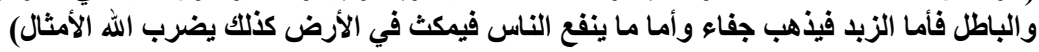

The concept of metaphor, in light of Janet Martin Soscike's point of view (1985), is just a sort of hyperbole by which one thing is utilized to be suggestive of an alternate. It is based on two essential elements: vehicle and tenor. In the above-mentioned verse from Quran, the words زبدا رابيا show the vehicle which is being the principle point of expression used. The tenor, as clarified in the verse itself, and affirmed by Islamic scholars, is Falsehood (really, false convictions). As a rule, the terms vehicle and tenor are substituted by "source" and 'target', separately. The proportional element between the target (or tenor) and source (or vehicle) may be alluded to as a "ground'. A percentage of the illustrations are common to the point that we don't even perceive the different method of expression or picture anything. Our focus goes straightforwardly to the target as opposed to the source. Such illustrations may be named as dead representations. A case is the utilization of the saying "fall" in the outflow 'becoming hopelessly enamored .'

A developed analogy is similar to an arrangement of related or various metaphors, for example, "the world is a stage representation" in Shakespeare works where men and ladies are additionally specified as 'performing artists'. In a compound illustration, the hyperbole is further qualified through descriptive words or qualifiers. At the point the subject is obviously reasonable from the setting or from recognition. Case in point saying 'we are blazing today' on an extremely hot day will be well-understood. Not in all cases is the likeness between the target and the source extremely clear, for example, in the illustration of 'rose and affection'. Such an outright metaphor makes individuals consider its importance and can possibly turned into a perpetual "picture" in individuals' brain connected with unique, expansive and noteworthy sensation of life, (for example, the utilization of "light" for 'truth'). The capable picture may be the main wellspring of communicating different message. At last, such unique metaphor shows an essential message from the creator that ought to be seen and reviewed. In spite of the fact that the use of imagination as a linguistic device is unquestionably across the board in the Qur'an, it is rich in both unique and outright metaphors .

$$
\text { (ومثلهم في الإنجيل كزرع أخرج شطأه فآزره فاستغلظ فاستوى على سوقه يعجب الزراع) }
$$

One of the profound metaphors in Quran is in this verse, which is about the image of the Prophet and his believers in the holy book and their illustration was depicted in the Bible. The simile starts with the conjunction) s with fat'ha on it) signifying 'like'; subsequently it is in the classification of a simile. The fundamental source is "seed" created further in the verse therefore turning into a broadened allegory. It appears that the deciphered importance of the general allegory is the development in quantities of the devotees and adherents when Prophet Mohammad (salla Allahu alaihi wa sallam) began explaining Islam as a religion. In that capacity the depiction may be seen as an intensifying one.

$$
\text { (يوم يكثف عن سلق) }
$$

In a similar track, the verse alludes to the Day of Judgment when individuals will be called upon to bow down upon the arrival of this Exposure, yet the individuals who never tried to bow down on the planet will be uncovered by being not able to do so again here. As per Tafseer Ibne-Katheer, the ahadith in both Bukhari and Muslim repeat the allegorical idea of Shin introduction without expounding it all the more unequivocally. Nonetheless, both the setting of the verse and as per a hadith with weaker sources, the Shin alludes to the Exposure of God the Al-relentless' Light. On the other hand, it could be some other Attribute of His, as indicated by Qur'an. Likewise, 
as per an elucidation by Ibn Abbas the importance alludes to the quick fear of that hard day (this understanding is imparted in both the interfaced sources). This last importance is additionally underpinned by reference to Arabic saying, since shins are uncovered by lifting up of one's piece of clothing when one is fleeing on a day of extreme calamity .

$$
\text { (مثل الذين ينفقون أموالهم في سبيل الله كمثل حبة أنبتت سبع سنابل في كل سنبلة مائة حبة والله يضاعف لمن يشاء والله واسع عليم) }
$$

This is an alternate expanded and compound illustration in which the figurative relationship is secured expressly and consequently it is actually a simile. Despite the fact that the target is the individuals who do the using, the target could also mean their wealth used for the sake of Allah, which is similar to a seed sown and will bring to the extent that from God's abundance as a solitary seed growing into a bushelful of grain .

$$
\text { (فمثله كمثل صفوان عليه تراب فأصابه وابل فتركه صلدا لا يقدرون على شيع مما كسبوا والله لا يهدي القوم الكافرين) }
$$

In the same track, the above verse is about the using of the individuals who do it only for show; prove by the way that their giving is typically followed by by displaying it in the public eye or helping to remember their 'great deed' to the alms taker, or it is followed by a mediocre treatment towards the alms taker. Again a similarity created through compound components, the principle target is the genuine nature of their alms giving.

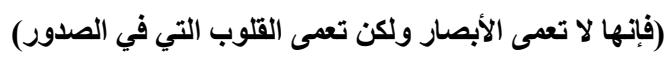

There are two metaphors in this verse. Heart is a well-known informal reference to 'sense', 'influence', and 'feeling'. Visual impairment (blindness) is likewise a somewhat basic representation of the state of foolishness, absence of knowledge, and emotional harshness.

\section{Conclusion and Results}

The present paper has tackled the metaphor in the Qur'an within the theoretical framework put forward by Lakoff and Turner (1989), known as the Cognitive Theory of Metaphor, where it has shown how the Qur'an is structured around the idea of the variety of meaning of lexical items, and how every correspondence between the two domains of "literal" and "non literal" can fit there. The use of such a metaphor makes the reader clarify and define the relationship between object and image. Meanwhile, this process serves two purposes: first, it forces the reader to participate actively in the Qur'an i.e. Consider its message and follow its teachings. Second, it gives him knowledge about something he did not know or only partly knew by making it analogous to something he can imagine. This is a fairly common resource in literary language as Lakoff and Turner admits that. Though these can be combined and elaborated in novel ways and expressed poetically in various ways, such variety starts from the small set of basic metaphors. Lakoff and Turner go on to assert that such basic metaphors may be composed or elaborated in new ways, but the same basic conceptual resources available to us all are still used. If this is not done, we would not understand them. Thus, as we have seen, the linguistic creativity of the Qur'an is extraordinary as such basic metaphors are used in novel unprecedented ways. Metaphorical usage in the Qur'an shows the imaginative use of conventional metaphors where we have novel metaphors offering us new ways and possibilities in the form of new unconventional conceptual metaphors to see the world around us. Meanwhile, most of the theoretical tenets of the cognitive approach to metaphor have been actually confirmed by the empirical findings of the present application. Clearly, the linguistic and rhetorical features of the Holy Quran continue to challenge linguists who struggle to convey the intended meaning of the Quranic verses. Linguists must depend on a number of dictionaries in both Arabic and English to determine the specific meaning of the words. A linguist must also consult the various commentaries of the Quran to obtain the appropriate interpretation of the Quranic verses. Thus, the present analysis in terms of conceptual metaphors may go some way towards a better understanding of religious reasoning.

\section{References}

Ali, Y. (1988). The Holy Quran: Text, Translation and Commentary. Elmhurst, NY: TahrikeTarsile Quran, Inc.

Black, M. (1962). Metaphor. In Models and Metaphors: Studies in Language and Philosophy. NY: Cornell University Press. 
Black, M. (1979). More about Metaphor. In A. Ortony (Ed.), Metaphor and Linguistic Theory (pp. 19-43). New York: Cambridge University Press.

Charteris-Black, J. (2004). Corpus Approaches to Critical Metaphor Analysis. London: Palgrave Macmillan. http://dx.doi.org/10.1057/9780230000612

Deignan, A. (1995). COBUILD English Guides 7: Metaphor. London: Harper Collins.

Geiger, R., \& Rudzka-Ostyn, B. (1993). Conceptualizations and Mental Processing in Language. New York: Moulton de Gruyter. http://dx.doi.org/10.1515/9783110857108

Goatly, A. (1997). The Language of Metaphors. Routledge: London.

Janet, S. (1985). Metaphor and Religious Language. Clarendon Press.

Knowles, M., \& Moon, R. (2005). Introducing Metaphor. New York: Routledge.

Lakoff, G. (1987). Women, Fire, and Dangerous Things: What Categories Reveal about the Mind. Chicago: The University of Chicago Press. http://dx.doi.org/10.7208/chicago/9780226471013.001.0001

Lakoff, G. (1988). Cognitive Semantics. In U. Eco, M. Santambrogio, \& P. Violi (Eds.), Meaning and Mental Representation. Bloomington and Indianapolis: Indiana University

Lakoff, G. (1990). The invariance hypothesis: Is abstract reason based on image-schemas? Cognitive Linguistics 1(1), 39-47. http://dx.doi.org/10.1515/cogl.1990.1.1.39

Lakoff, G. (1993). The Contemporary Theory of Metaphor. In A. Ortony (Ed.), Metaphor and Thought (pp. 202-251). Cambridge: Cambridge University Press. http://dx.doi.org/10.1017/CBO9781139173865.013

Lakoff, G. (2008). The Neural Theory of Metaphor. In J. R. Gbbs (Ed.), The Cambridge Handbook of Metaphor and Thought (pp. 17-38). Cambridge: Cambridge University Press. http://dx.doi.org/10.1017/CBO9780511816802.003

Lakoff, G., \& Johnson, M. (1980). Metaphors We Live By. Chicago: The University of Chicago Press.

Lakoff, G., \& Turner, M. (1989). More Than Cool Reason: A Field Guide to Poetic Metaphor. Chicago: The University of Chicago Press. http://dx.doi.org/10.7208/chicago/9780226470986.001.0001

Leech, G. N. (1969). A Linguistic Guide to English Poetry. London: Longman.

Leech, G. N. (1974). A Linguistic Guide to English Poetry. London: Longman.

Merriam Webster's Collegiate Dictionary. (1999). Tenth Edition. Merriam Webster Incorporated.

Miller, E. (1979). Metaphor and Political Knowledge. The American Political Science Review, 73(1), 155-170. http://dx.doi.org/10.2307/1954738

Miller, S. (1998). Understanding \& Creating Editorial Cartoons. Wisconsin: Knowledge Unlimited Inc.

Murray, K., \& Moon, R. (2006). Introducing Metaphor. Routledge.

Ortony, A. (1979). Metaphor and Thought. Cambridge: Cambridge University Press.

Richards, I. A. (1936). The Philosophy of Rhetoric. New York: Oxford University Press.

Ross, D. W. (1952). The Works of Aristottle. Oxford: Clarendon Press.

Swanson, D. R. (1978). Toward A Psychology of Metaphor. Critical Inquiry, 5(1), 163-166. http://dx.doi.org/10.1086/447979

Turner, M. (1990). Aspects of the Invariance Hypothesis. Cognitive Linguistics, 1(2), 247-255.

Turner, M. (1993). An Image-Schematic Constraint on Metaphor. In R. A. Geiger \& B. Rudzka-Ostyn (Eds.), Conceptualizations and Mental Processing in Language. New York: Moulton de Gruyter. http://dx.doi.org/10.1515/9783110857108.291

Ullmann, S. (1978). Semantic Universals. Universals of Language (pp. 217-262). MIT Press.

\section{Copyrights}

Copyright for this article is retained by the author(s), with first publication rights granted to the journal.

This is an open-access article distributed under the terms and conditions of the Creative Commons Attribution license (http://creativecommons.org/licenses/by/3.0/). 